\title{
Novel Management and Screening Approaches for Haematological Complications of Gaucher's Disease
}

\author{
Pilar Giraldo ${ }^{1,2}$ \\ Marcio Andrade-Campos ${ }^{2,3}$ \\ 'Haematology, Hospital Quironsalud, \\ Zaragoza, Spain; ${ }^{2}$ Foundation FEETEG, \\ Zaragoza, Spain; ${ }^{3}$ Haematology \\ Department, Hospital del Mar, Barcelona, \\ Spain
}

\begin{abstract}
Purpose: Gaucher disease (GD) is the most common lysosomal storage disorder. The principal manifestations for its diagnosis and further monitoring include haematological manifestations such as anaemia, thrombocytopaenia, spleen enlargement, and bleeding disorders, among others. This review aims to summarise and update the role of haematological complications in GD diagnosis and follow-up, describe their management strategies, and to use these indicators as part of the diagnostic approach.
\end{abstract}

Materials and Methods: A systematic review following the recommendations of PRISMA-P 2020 was carried out. Publications indexed in the databases PubMed, Embase, Science Open, Mendeley, and Web of Science were electronically searched by three independent reviewers, and publications up to June 2021 were accessed. A total of 246 publications were initially listed, of which 129 were included for further review and analysis. Case reports were considered if they were representative of a relevant hematologic complication. Results: From the first review dated in 1974 to the latest publication in 2021, including different populations confirmed that the haematological manifestations such as thrombocytopaenia and splenomegaly at diagnosis of GD type 1 are the most frequent features of the disease. The incorporation of haematological parameters to diagnosis strategies increases their costeffectiveness. Hematologic parameters are part of the scoring system for disease assessment and the evaluation of therapeutic outcomes, providing reliable and accessible data to improve the management of GD. However, cytopaenia, underlying coagulation disorders, and platelet dysfunction need to be addressed, especially during pregnancy or surgery. Long-term haematological complications include the risk of neoplasia and immune impairment, an area of unmet need that is currently under research

Conclusion: Haematological features are key for GD suspicion, diagnosis, and management. Normalization of hematological parameters is achieved with the treatment; however, there are unmet needs such as the underlying inflammatory status and the long-term risk of hematologic neoplasia.

Keywords: Gaucher disease, long-term complications, bleeding disorders, haematologic manifestations

\section{Introduction}

Gaucher disease (GD, OMIM230800) is the most prevalent of the lysosomal storage diseases (LSD). It affects approximately 1 in 40,000-100,000 inhabitants of the general population, but its frequency in Ashkenazi Jews is as high as $\sim 1$ in $850 .^{1-5} \mathrm{GD}$ is classically described as three types according to neurological involvement. Type 1 GD (non-neuronopathic) is the most common form of presentation. 
Type 3 is characterised in turn by three sub-types with different neurological manifestations (epilepsy, ataxia, saccadic eye movements, seizures) and other nonneurological features like heart valve infiltration and kyphosis. Type 2 GD is the most severe presentation with acute/subacute neurological impairment early in life (newborns to 1 year old); GD2 patients have a very short lifespan, usually around 2 years of age..$^{3-6}$

GD is considered the prototype of the LSD, and was the first LSD to have a specific therapy. Among its multisystemic impairments, it is the LSD with the most implications compromising the haematopoietic system in terms of manifestations at diagnosis, follow-up, and development of complications. ${ }^{1-3}$

Haematological manifestations are key features for disease suspicion, as cytopaenia and spleen enlargement are almost universal in untreated patients. Among the most frequent manifestations at diagnosis, according to International Collaborative Gaucher Group (ICGG) and other registries, are anaemia (29\%), thrombocytopaenia (62\%), splenomegaly (91\%), bleeding $(20.6 \%)$, and bone pain $(57.9 \%) .{ }^{7,8}$ In our local experience, almost $80 \%$ of GD1 cases undergo a bone marrow exam as part of their patient journey for diagnosis, although a bone marrow aspirate is not necessary to make a diagnosis of GD. ${ }^{8}$

The target cell in this lysosomal disease is a blood cell, the monocyte-macrophage. Monocyte-macrophages originate from the common myeloid progenitor in the bone marrow; they express acid phosphatase, CD68, CD14, and HLA class II. The classical Gaucher cells are macrophages engorged with a PAS+ substrate and a crinkled paper morphology; they can be found in different tissues, but especially in the bone marrow and spleen. Gaucher cells also express CD163, CCL18, and the interleukin-1 receptor antagonist, characteristic of alternatively activated or M2 macrophages. The altered morphology of Gaucher cells is secondary to the defect in the enzymatic activity of the lysosomal hydrolase $\beta$-glucocerebrosidase; these cells and mainly all phagocytic cells show an impairment in their multiple functions that leads to multi-systemic repercussions. ${ }^{9,10}$

The hematopoietic system of an adult person produces more than 400 billion cells daily. With this high turnover, cellular components, especially membrane remnants, are constantly destroyed and phagocytosed by macrophages to be broken down and reused in the manufacture of new cells. ${ }^{9}$ The accumulation of undegraded phagocytosed material in the cytoplasm of the macrophage due to impaired enzyme function leads to a thickening of the cells, which transform into Gaucher cells and displace the normal cellular network, increasing the size of the spleen and liver (the organs with the highest macrophage content), which also contributes to blood cell sequestration and increased anaemia and/or thrombocytopaenia. In the bone marrow, the displacement of haematopoiesis by Gaucher cell accumulation causes anaemia and thrombocytopaenia, which often leads to the suspicion of a haematological malignancy. It should be noted that, in several haematological malignancies, macrophages engorged with excess cellular material in the process of destruction are visualised in the bone marrow with a similar appearance to Gaucher cells (they are called pseudo Gaucher cells). ${ }^{11}$ For that reason, Gaucher cells are not a pathognomonic finding of GD, but usually a finding that leads the diagnostic suspicion.

Other accompanying haematological changes are hyperferritinemia, ${ }^{12,13}$ polyclonal or monoclonal gammopathy, ${ }^{14}$ and other immune abnormalities as a decrease in the overall B-cells and an increase in NK and NK/T-cell population in the peripheral blood ${ }^{15}$ are found with great frequency and contribute to identifying the underlying inflammatory component derived from monocyte-macrophage dysfunction.

Several haemostatic abnormalities have been described in GD, including prolonged prothrombin time (PT) and activated partial thromboplastin time (APPT), indicative of deficiencies in factor X, factor $\mathrm{V}$, and factor XI (more frequent in Ashkenazi Jews). Also have been reported, but with little incidence deficiencies secondary to liver failure and rarely associated with von Willebrand disease. ${ }^{16}$ Functional platelet defects such as abnormal platelet aggregation or adhesion defects could contribute to bleeding diathesis. ${ }^{17}$

In this review, a search was performed in the literature, focused on the haematological manifestations and complications with the aim of updating their incidence, describing novel management strategies, and highlighting these strategies as a part of the diagnostic work-up.

\section{Materials and Methods}

\section{Systematic Literature Review Objectives}

In this study, a systematic review was carried out in accordance with the Preferred Reporting Items for Systematic Review and Meta Analyses (PRISMA) guidelines. ${ }^{18}$ 


\section{Eligibility Criteria}

The inclusion criteria used for the selection of articles were all published original articles or review articles or registry data and guidelines about the diagnosis and follow-up of GD. Reports of single-case studies were considered if they were representative of a relevant hematologic complication.

\section{Search Strategy}

PubMed, Embase, Science Open, Mendeley, and Web of Science databases were electronically searched for relevant papers published up to June 2021, without language limitations. English descriptors were adapted according to the database. The following search strategy was entered into the database: ("haematological manifestations" OR "haematological complications" OR "haematological data" OR "screening haematological diagnosis") AND ("Gaucher disease").

A secondary manual search of the reference lists of the relevant articles was also carried out. In addition to these database searches, numerous permutations of our search terms (keywords: bone marrow, spleen, cytopaenia, bleeding, B-cell malignancy, gammopathy) were entered into Google Scholar and thoroughly searched for any additional articles not found in the database searches.
Two independent reviewers developed an Excel database in order to record the studies that met the inclusion criteria, including the abstract, title, date of publication, authors, and journal in order to facilitate the review and selection process.

\section{Results}

We reviewed and selected a total of 246 articles, including two online books updated annually. In the first review, the selection was reduced to 213 , as shown in the flow chart in Figure 1. We excluded articles that referred only to basic research results without translatability, treatment results referring exclusively to bone disease or analysis of results that did not include haematological alterations or complications, to finally select 129 works that were included in this review.

\section{Haematological Manifestations and Screening Programmes}

The reviewed articles, from the first review from 1974 to the latest publication in 2021, included analyses of different populations, all of them with haematological manifestations such as thrombocytopaenia and splenomegaly at diagnosis. GD type 1 was the most frequent manifestation of the disease. Anaemia and hepatomegaly were also a constant in the clinical picture. The intensity and variability of these manifestations was very wide due to the

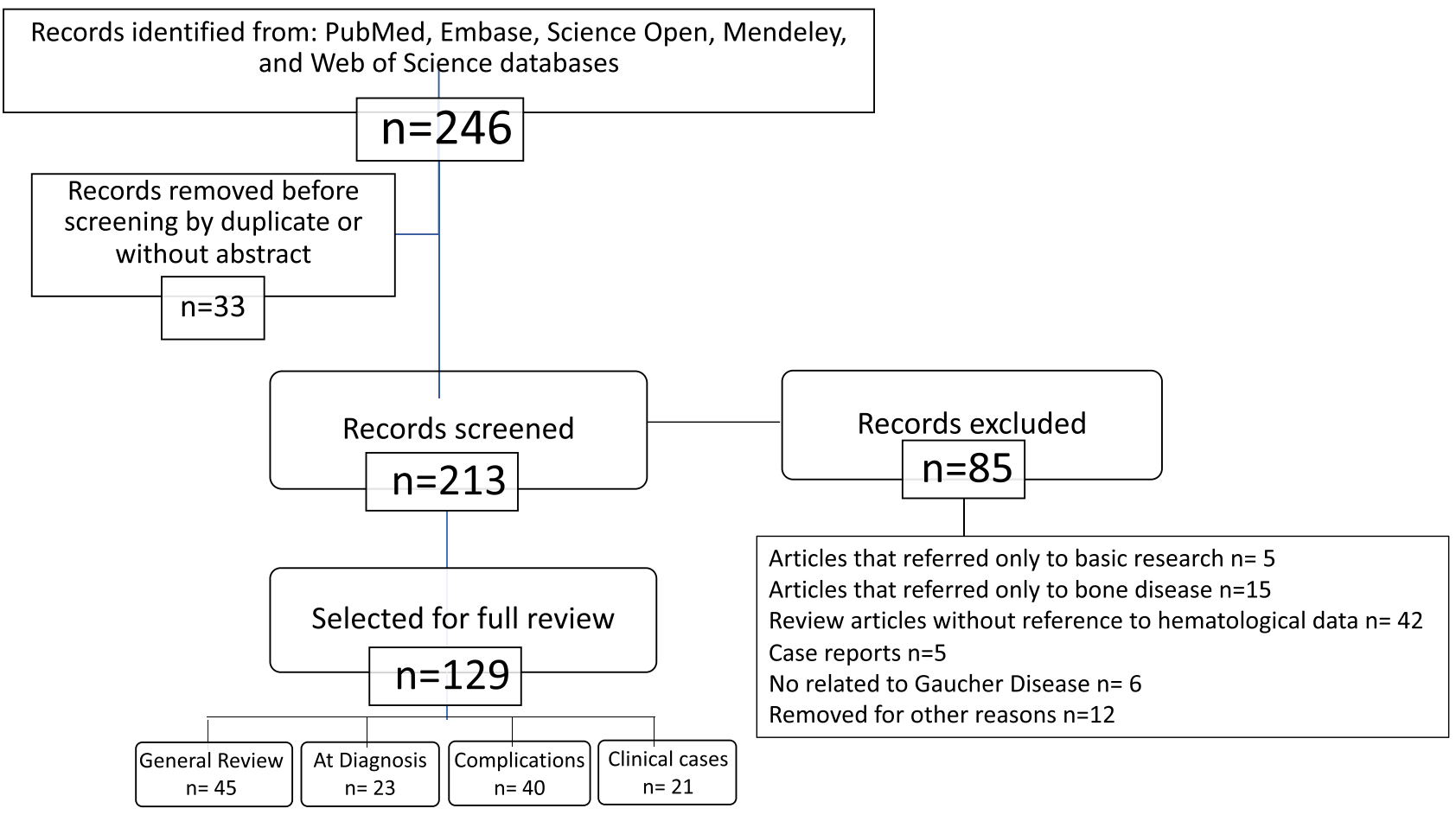

Figure I Flow chart. Identification of studies. 
heterogeneity of the disease. Haematological manifestations may present as early as in the first months of life or go unnoticed for decades. Table 1 shows the selected publications in which data on haematological variables are referred to diagnosis in different populations; the majority of the selected articles were reviews. ${ }^{6,19-38}$

In the last decade, several screening programmes for lysosomal diseases have been developed in different populations using dried blood spots for early detection before symptoms appear. In a New York study, 15 GD cases were diagnosed, ${ }^{39}$ while none were found in a Mexican study, ${ }^{40}$ 2 GD cases in an Italian study, ${ }^{41}$ and 5 GD cases in an Illinois study. ${ }^{42}$ These studies were performed using both enzymatic analysis and multiplexed tandem mass spectrometry. ${ }^{43}$ In China, using a fluorometric assay, 1 GD case was diagnosed. ${ }^{44}$ In Taiwan, using mass spectrometry, no cases were diagnosed, ${ }^{45}$ and in Brazil, using microfluidics, 2 GD cases were identified. ${ }^{46}$ There is much controversy over the detection of false positives. ${ }^{47}$ This approach is controversial because the incidence of cases in general population is low $(\sim 1 / 100,000$ live births) in different populations and its application is only promoted in those communities with a high incidence of cases, such as in the Ashkenazi Jewish population, where the incidence is $1 / 850$ births. Recently, the use of genetic analysis panels has been explored. ${ }^{48}$ Active search for patients with subclinical disease by screening for cases with mild to moderate thrombocytopaenia and splenomegaly has provided variable results with generally low identification rates, ie, $4 / 73,{ }^{49} 55 / 787,,^{50} 7 / 196,{ }^{51}$ and $2 /$ $1000 .^{52}$ Another different approach is the family study, the current recommendation for low-incidence populations includes familial studies after an index case has been identified. In our practice, more than $10 \%$ of the GD cases included in the Spanish Registry were diagnosed following this recommendation. ${ }^{53}$

\section{GD Biomarkers and Haematological Features}

Biomarkers are useful tools to help in the disease diagnosis and follow-up. GD is the lysosomal disease that has the most validated biomarkers, which offer objective information about the situation of the disease to detect early complications and measure the response to therapy.

Chitotriosidase is an enzyme produced by activated macrophages; its activity correlates with the burden of the disease and is modified with treatment. Therefore, it is a useful tool to monitor the treatment response; however, other systemic inflammatory statuses or acute conditions such as systemic infections or acute GD complications can increase chitotriosidase activity. In addition, about $6 \%$ of the Caucasian population has a 24 base pair duplication in homozygosity in the CHIT1 gene encoding the enzyme and lacks chitotriosidase activity. ${ }^{54}$ The quantification in plasma of the substrate sphingolipid has rapidly become an important biomarker for diagnosis; glucosylsphingosine (Lyso-Gb1) is increased in GD, with rapid reduction after enzymatic therapy because it specifically reflects substrate accumulation in the body. Therefore, some screening studies have already incorporated these two determinations in combination with a minimum clinical haematological feature for suspicion to identify patients affected by GD. A study carried out by Fuller et al confirmed 9 GD patients by increased chitotriosidase activity among 1415 samples. ${ }^{55}$ Recently, a study by Tang et al determined glucosylsphingosine in dried blood spot (DBS) samples of 142 high-risk patients with splenomegaly and/or thrombocytopaenia and

Table I Studies That Refer to Haematological Manifestations at Diagnosis

\begin{tabular}{|l|l|l|l|l|l|}
\hline Author Year (Reference) & No Cases & Anaemia (\%) & Thrombocytopaenia (\%) & Hepatomegaly (\%) & Splenomegaly (\%) \\
\hline Medoff and Bayrd $1954^{20}$ & 29 & & 83.0 & 79.0 & 100 \\
\hline Giraldo P et al $2000^{27}$ & 155 & 46.0 & 83.5 & 61.2 & 71.7 \\
\hline Thomas et al $2012^{31}$ & 45 & 20.0 & 59.0 & 44.0 & 82.0 \\
\hline Essabar et al $2015^{23}$ & 11 & 56.0 & & 100 & 100 \\
\hline Mistry et al $2017^{30}$ & 212 & 46.6 & 81.0 & 68.0 & 81.0 \\
\hline Weinreb et al $2021^{28}$ & 310 & 40.6 & 100 & 40.0 & 90.0 \\
\hline
\end{tabular}


identified 52 GD patients. ${ }^{56}$ Other strategies using algorithms have been tried. ${ }^{57-59}$

Screening programmes based on haematological indicators or biomarker determinations are shown in Table 2.

\section{Coagulation Disorders}

Bleeding is a frequent manifestation that occurs at different stages of the disease; at diagnosis, it is a symptom usually secondary to thrombocytopaenia, but a variety of coagulation factor abnormalities (fibrinogen, factor II, VII, VIII, X, XII), acquired coagulation factor deficiencies including von Willebrand factor (vWF) deficiency and specific inherited coagulation factor deficiencies (factor XI deficiency among
Ashkenazi Jews) have been described. In addition, abnormal platelet aggregation and adhesion can be present at diagnosis and may contribute to bleeding diathesis. $^{3,16,17,60-69}$ Table 3 shows the most relevant studies.

It is important to carry out a haemostatic evaluation including platelet count and basic haemostatic tests such as fibrinogen, prothrombin time, activated partial thromboplastin time as well as platelet function tests, especially if the patient is to undergo surgery to compensate for deficiencies.

In special situations, such as pregnancy, these abnormalities are of special importance, requiring the monitoring of haemostatic function and cellular counts to minimise the bleeding risk. ${ }^{70-72}$

Table 2 Screening Programmes for Lysosomal Diseases Based on Haematological Data or Biomarkers

\begin{tabular}{|c|c|c|c|c|c|}
\hline $\begin{array}{l}\text { Author Year } \\
\text { (Reference) }\end{array}$ & $\begin{array}{l}\text { Period } \\
\text { Study }\end{array}$ & $\begin{array}{l}\text { No Cases } \\
\text { Screened }\end{array}$ & $\begin{array}{l}\text { No Cases } \\
\text { Identified }\end{array}$ & $\begin{array}{l}\text { Positive Predictive Value } \\
\text { (\%) }\end{array}$ & $\begin{array}{l}\text { General Prevalence of } \\
\text { GD }\end{array}$ \\
\hline Fuller et al $2011^{55}$ & 2003-2007 & 1415 & 9 & & Australia (retrospective) \\
\hline Motta et al $2015^{51}$ & $2010-2013$ & 196 & 7 & 18.4 & Italy $1 / 100,000$ \\
\hline Huang et al $2020^{50}$ & $2016-2019$ & 786 & 55 & 37.4 & China $1 / 80,000$ \\
\hline Miyamoto et al $2021^{52}$ & $2016-2018$ & 994 & 12 & & Japan I/330,000 \\
\hline Tang et al $2021^{56}$ & & 142 & 52 & & China \\
\hline
\end{tabular}

Abbreviation: GD, Gaucher disease.

Table 3 Haemostatic Abnormalities

\begin{tabular}{|c|c|c|c|c|c|}
\hline $\begin{array}{l}\text { Author Year } \\
\text { (Reference) }\end{array}$ & $\begin{array}{l}\text { No } \\
\text { Cases }\end{array}$ & Decreased Factors & $\begin{array}{l}\text { Platelets } \\
\text { Dysfunction }\end{array}$ & $\begin{array}{l}\text { Prolongation } \\
\text { PT/APPT }\end{array}$ & $\begin{array}{l}\text { Increased D Dimer or } \\
\text { Reduction PC/PS }\end{array}$ \\
\hline Billett et al $1996^{60}$ & 9 & II, V, VIII, XI & - & Yes & - \\
\hline Hollak et al $1997^{61}$ & 30 & II; V; VII; VIII; IX, X, XI, XII & Yes & Yes & Yes \\
\hline Katz et al $1999^{62}$ & 22 & V, VIII, IX, XI, XII & - & Yes & - \\
\hline Giona et al $2006^{63}$ & 15 & $\begin{array}{l}\text { II, V, VII, VIII, IX, X, XI, XII, } \\
\text { vWF }\end{array}$ & Yes & Yes & - \\
\hline Deghady et al $2006^{64}$ & 10 & II, V, VII, VIII, IX, X, XI, XII & - & Yes & - \\
\hline Spectre et al $2011^{17}$ & 48 & - & Yes & - & - \\
\hline Givol et al $2012^{66}$ & 7 & $\mathrm{XI}$ & Yes & No & - \\
\hline Mitrovic et al $2012^{65}$ & 31 & $\begin{array}{l}\text { II, V, VII, VIII, IX, X, XI, XII, } \\
\text { vW }\end{array}$ & Yes & Yes & - \\
\hline $\begin{array}{l}\text { Komninaka et al } \\
2020^{67}\end{array}$ & 29 & VIII, vWF, ADAMTSI3 & Yes & Yes & Yes \\
\hline
\end{tabular}

Abbreviations: PT, prothrombin time; APPT, activated partial thromboplastin time; PC, C protein; PS, S protein; vWF, von Willebrand factor. 


\section{Treatment Effect in Haematological Parameters}

The goals of treatment focus on three main areas: recovery of hematologic parameters and a reduction in visceral volumes and bone marrow infiltration. Reversal of haematological alterations is one of the main goals of treatment and is achieved in more than $90 \%$ of cases with both enzyme replacement therapy and substrate reduction therapy. However, the underlying inflammatory process is not fully reversible with available treatments, and there is speculation about the importance of this situation in the functioning of the immune system and the development of long-term complications of the disease. ${ }^{22}$ The application of scoring systems and monitoring guides facilitates the traceability of the response and monitoring indicators. Haematological parameters are easily measurable by any specialist. ${ }^{29,73-79}$ However, there are other haematological alterations that can be observed in the follow-up of patients, such as megaloblastic features of the red blood cells, accompanied or not by folate or vitamin B12 deficiency. ${ }^{80}$

All the current available therapies have firmly demonstrated an improvement in haematological parameters, and improvement is rapid during the first 6 months, but continues progressively with the majority of patients normalising blood counts in 2-5 years.

\section{Inflammation and Haematological Alterations}

The methods to assess the inflammatory status and immunological alterations are not well defined in GD, although there are some determinations that may help to predict immune status and detect haematological complications that may arise in the long term. Hyperferritinaemia and immunologic abnormalities such as polyclonal and monoclonal gammopathy are detected very often both in children and adults. ${ }^{12-15,81}$ Persistent immune alterations such as changes in T/B-cell populations, polyclonal gammopathy, and the cytokine profile, especially in splenectomised patients, have been related to long-term complications. ${ }^{37,82-84}$ Also, a general increased incidence of haematological malignancies has been reported in GD patients since the early 1990s. ${ }^{85-87}$

Hyperferritinaemia and gammopathies also play a role in GD diagnosis, as they may be the reason for consultation with haematology in previously undiagnosed cases. ${ }^{12,13}$ Isolated cholestasis ${ }^{88}$ or elevated transaminases and hepatomegaly may be confounding data in the differential diagnosis with other entities. ${ }^{89}$

\section{Haematological Complications}

Long-term complications in GD patients include a high risk of developing haematological malignancies; this risk has been estimated to be between 14.7-fold and 51.1-fold according to data from the International Collaborative Gaucher Group (ICGG) registry. ${ }^{90}$ There is a predominance of hematologic neoplasms derived from the B lymphoid lineage and linked to the monoclonal hypergammaglobulinemia so frequently detected in these patients. $^{91-98}$

Nevertheless, there are discrepancies related to the relative risk according to different studies. B-cell and plasma cell malignancies such as multiple myeloma are the most commonly described. The risk of multiple myeloma is 5.9-fold (95\% CI 2.8-10.8) according ICGG data. ${ }^{90}$ In other studies, the relative risk was higher at 25 fold (95\% CI 9.17-54.40). ${ }^{91}$ Table 4 shows the most significant data.

The pathogenesis of these complications has been interpreted as secondary to the chronic immunological disturbances with a predisposition to develop chronic inflammation following chronic B-cell stimulation. An increase in cytokines such as IL-1, IL-6, IL-10, CCL18, and TNF- $\alpha$ has been demonstrated in several experimental studies $^{81,82}$ as well as the implication of complement factors $^{82}$ and their relationship with the presence of gammopathies in GD1 patients. ${ }^{99,100}$ In mouse models of Gaucher's disease-associated gammopathy, monoclonal immunoglobulin has been shown to be reactive against lyso-glucosylceramide. ${ }^{101,102}$ The abnormalities in T-cell function could explain the increased incidence of other haematological neoplasias as acute lymphoblastic leukaemia, chronic lymphocytic leukaemia, Hodgkin's disease, and non-Hodgkin's lymphoma. ${ }^{103-107}$ In isolated cases, the diagnosis of GD has been reached through the study of a hematological alteration such as monoclonal gammopathy, suspicion of multiple myeloma due to pathological fracture, or thalassemia suspicion. More than 25 isolated cases of haematological neoplasms have been reported, some of them diagnosed simultaneously with GD. ${ }^{108-111}$ Most of the cases correspond to B-lineage lymphoid neoplasms, but other sporadic cases of nonneoplastic haematological disorders have been observed $^{112-115}$ (Table 5). Co-existence of isolated cases of acute myelogenous leukaemia, chronic myelogenous leukaemia, myelodysplastic syndrome, or myeloproliferative neoplasm have also been described. ${ }^{116-123}$ 
Table 4 Haematological Complications in GDI

\begin{tabular}{|c|c|c|c|c|c|}
\hline Author Year (Reference) & No Cases & Hyperimmunoglobulin & Haematol Neoplasia & Risk (\%) & Others \\
\hline Shiran et al $1993^{85}$ & 48 & - & 5 & 10.4 & - \\
\hline Gielchinsky et al $2001^{80}$ & 89 & - & - & & BI2 deficiency (36) \\
\hline Rosenbloom et al $2005^{90}$ & 2742 (ICGG) & - & 10 (MM) & 5.9 & - \\
\hline de Fost et al $2005^{93}$ & $|3|$ & - & 5 & $12.7 *$ & - \\
\hline Zimran et al $2005^{91}$ & 505 & - & 8 & 14.6 & - \\
\hline Wine et al $2007^{81}$ & 23 paediatrics & Yes & - & - & - \\
\hline Taddei et al $2009^{94}$ & 403 & - & 8 & $3.45 * *$ & - \\
\hline Weinreb et al $2013^{96}$ & 184 & - & 8 & 14.6 & - \\
\hline Rodic et al $2013^{99}$ & 27 & Yes & II (MGUS) & - & - \\
\hline
\end{tabular}

Notes: *The relative risk for MM 5I.I; **The relative risk for MM 25.0.

Abbreviations: GDI, Type I Gaucher disease; ICGG, International Collaborative Gaucher Group; MM, multiple myeloma; MGUS, monoclonal gammopathy of undetermined significance.

\section{Discussion}

Undoubtedly, the haematological manifestations at diagnosis of GD type 1, such as thrombocytopaenia and splenomegaly, are key in the diagnosis of the disease. However, the intensity and variability of these manifestations is very wide due to the heterogeneity of the disease and are therefore not specific. ${ }^{1-8}$ In the various screening programmes in which these variables (thrombocytopaenia and splenomegaly) have been used to identify undiagnosed patients, the number of cases detected was low, ie, less than $10 \%$ in selected populations and with analyses carried out over long periods of time (between 2 and 4 years). ${ }^{39-46}$ Newborn screening programmes also have very low success rates for GD, so they do not appear to be costeffective outside high-risk populations, with too many probands to identify a very small number of subjects, regardless of the used test (enzyme activity by microfluidics or mass spectrometry, combined with biomarkers or mass genetic analysis). ${ }^{47}$ Newborn screening programs are also controversial because of the detection of potentially asymptomatic or oligosymptomatic cases or a high number of false positives, which may have ethical repercussions in terms of parental stress, overmedication or others. This type of search is more applicable in populations with a high prevalence of cases or in family studies. Some approaches have also been used to apply models based on algorithms and methods based on a scoring system by Delphi initiatives in children $^{57}$ and adults $^{58}$ with a predictive value of around 0.80 in a series of already diagnosed patients. It seems more effective to insist on training programmes for specialists, both in paediatrics and among primary care physicians, haematologists, internists, rheumatologists, and undergraduates. ${ }^{124-126}$

Splenectomised GD patients generally suffer from increased bone and liver deposits and therefore have increased bone complications and increased susceptibility to infection. It is a therapeutic procedure that should be avoided in GD. ${ }^{1-4}$

Despite the general attention to cytopaenia, we have highlighted the importance of paying attention to the correct assessment of haemostatic parameters. ${ }^{60}$ Bleeding is a frequent clinical manifestation in patients with GD and is secondary not only to the thrombocytopaenia that most patients present at diagnosis, but to numerous alterations in coagulation factors, von Willebrand factor, and platelet dysfunction, even with normal platelet counts. ${ }^{61-68}$ It is of special interest to keep these data in mind in risky situations such as pregnancy and delivery, surgical interventions, and dental extractions, and to establish correct preventive measures. $^{62,66,69-72}$

In the follow-up of patients, cell counts are mandatory parameters for periodic assessment, whether the patients are on treatment or not. ${ }^{22,73-76}$ These are sensitive indicators in the evaluation of the response, but other parameters must also be considered. ${ }^{77-79}$ Vitamin B12 deficiency is present more frequently in patients with GD than in the general population, so in situations of anaemia not resolved by treatment, the morphology of red blood cells must be monitored to rule out 
Table 5 Cases Reported with Co-Existence of GD and Hematological Diseases

\begin{tabular}{|c|c|c|}
\hline $\begin{array}{l}\text { Author Year } \\
\text { (Reference) }\end{array}$ & Haematol Neoplasia & $\begin{array}{l}\text { Non-Neoplastic } \\
\text { Haematol }\end{array}$ \\
\hline Lester et al $1984^{115}$ & - & ITP \\
\hline $\begin{array}{l}\text { Petrides et al } \\
1998^{117}\end{array}$ & CML & - \\
\hline $\begin{array}{l}\text { Haliloglu et al } \\
1999^{1 / 2}\end{array}$ & & Budd-Chiari \\
\hline Webb et al $2011^{122}$ & $\begin{array}{l}\text { Chronic } \\
\text { myeloproliferative } \\
\text { neoplasia }\end{array}$ & - \\
\hline $\begin{array}{l}\text { Miri-Moghaddam } \\
\text { et al } 2011^{113}\end{array}$ & - & $\alpha$-thalassaemia \\
\hline $\begin{array}{l}\text { Ranade et al } \\
2013^{103}\end{array}$ & LAL & \\
\hline $\begin{array}{l}\text { Villarrubia et al } \\
2014^{1 / 8}\end{array}$ & MDS (del5q) & - \\
\hline Kubo et al $2014^{119}$ & - & $\begin{array}{l}\text { Epidural } \\
\text { haematoma }\end{array}$ \\
\hline Noya et al $2018^{120}$ & CML & - \\
\hline Kose et al $2019^{114}$ & - & $\begin{array}{l}\text { Severe } \\
\text { neutropaenia }\end{array}$ \\
\hline $\begin{array}{l}\text { Ruchlemer et al } \\
2020^{121}\end{array}$ & MDS \& ICUS & - \\
\hline Maity et al $2021^{116}$ & AML & - \\
\hline
\end{tabular}

Abbreviations: GD, Gaucher disease; ITP, immune thrombocytopenia; CML, chronic myeloid leukaemia; LAL, lymphoblastic acute leukaemia; MDS, Myelodysplastic syndrome; ICUS, idiopathic cytopenia of undetermined significance; AML, acute myeloid leukaemia.

megaloblastosis, and vitamin B12 and folate levels in the blood must be determined periodically. ${ }^{80}$ Also, in cases with persistent thrombocytopaenia, the association of immune thrombocytopaenia must be ruled out. ${ }^{115}$

Regarding the current concerns about the risk of neoplastic processes, eg, haematological neoplasms, ${ }^{90-98}$ the origin of this association is still under debate. However, the sphingolipid that accumulates most in this disease, ceramide, is involved in the regulation of cellular signal transduction, in cellular oxidative stress, and in cell death. ${ }^{127-129}$ Therefore, the whole cellular regulatory system could be affected, which is a matter of ongoing debate. Moreover, the contribution of the underlying chronic inflammatory state is important in lysosomal diseases, with permanent activation of the immune system as a result of macrophage activation and the secretion of cytokines, causing immune system dysfunction. ${ }^{81-83}$ The recommendation is to monitor the presence of polyclonal and monoclonal gammopathies in patients by performing an annual proteinogram, quantification of immunoglobulins, ferritin, and C-reactive protein levels $;{ }^{123}$ the determination of other parameters such as complement factors and lymphocyte populations may help to understand better the functioning of the immune system, but these tests are expensive and not generally available. Also, there are still not enough data for an appropriate interpretation of their impact or changes with therapy.

Recently, the influence of modifier genes in the appearance of neoplasms in GD has also been considered, but this is probably a casual association as occurs in some patients with $B C R / A B L, J A K 2$, or MSH6 mutations and is due to chance. ${ }^{120,122,123}$ There is no justification for a systematic panel study of genes related to different neoplasms, except for research purposes.

\section{Conclusion}

In this review, an extensive search of the literature was performed. Haematological manifestations are without any doubt a universal feature of GD patients. The variability of their presentation is related to the age of the patient, but mostly with the severity of the disease. Despite the presence of cytopaenia, coagulation complications can also appear in a non-small number of patients and treating physicians need to be aware of it, especially in situations such as pregnancy or surgery. Massive screening strategies are expensive, but programmes that include a minimum of clinical suspicion with haematological parameters are more cost-effective; moreover, awareness strategies among the different medical specialties are a continuous need. There are still unmet needs in the understanding and managing of haematological complications, such as the interpretation and evaluation of the risk for long-term complications or the immune imbalance before and during therapy.

\section{Acknowledgments}

We would like to acknowledge the FEETEG foundation for their assistance with the study and the patient association for collaboration and for the data provided in the performance of this study. 


\section{Disclosure}

Dr Marcio Andrade-Campos report personal fees from Sanofi-Genzyme, personal fees from Takeda-Shire, personal fees from Astra Zeneca, outside the submitted work. The authors report no other conflicts of interest in this work.

\section{References}

1. Cox TM, Schofield JP. Gaucher's disease: clinical features and natural history. Baillieres Clin Haematol. 1997;10:657-689. doi:10.1016/S0950-3536(97)80033-9

2. Grabowski GA. Phenotype, diagnosis, and treatment of Gaucher's disease. Lancet. 2008;372:1263-1271. doi:10.1016/S01406736(08)61522-6

3. Pastores GM, Hughes DA. Gaucher disease. In: Adam MP, Ardinger HH, Pagon RA, et al., editors. GeneReviews ${ }^{\circledR}$ [Internet]. Seattle (WA): University of Washington, Seattle; 1993-2021. July 27, 2000 [updated June 21, 2018].

4. Stirnemann J, Belmatoug N, Camou F, et al. A review of Gaucher disease pathophysiology, clinical presentation and treatments. Int J Mol Sci. 2017;18:441. doi:10.3390/ijms18020441

5. Nalysnyk L, Rotella P, Simeone JC, et al. Gaucher disease epidemiology and natural history: a comprehensive review of the literature. Hematology. 2017;22:65-73. doi:10.1080/ 10245332.2016.1240391

6. Baris HN, Cohen IJ, Mistry PK. Gaucher disease: the metabolic defect, pathophysiology, phenotypes and natural history. Pediatr Endocrinol Rev. 2014;12(Suppl 1):72-81.

7. Grabowski GA, Zimran A, Ida H. Gaucher disease types 1 and 3: phenotypic characterization of large populations from the ICGG Gaucher registry. Am J Hematol. 2015;90(Suppl 1):S12-8. doi:10.1002/ajh.24063

8. Andrade-Campos M, Capablo JL, Fraile JJ, et al. Twenty-five years diagnosing Gaucher's disease in Spain, what we have learned? Blood. 2018;132(Supplement 1):1110. doi:10.1182/ blood-2018-99-115474

9. Gordon S, Plüddemann A, Martinez Estrada F. Macrophage heterogeneity in tissues: phenotypic diversity and functions. Immunol Rev. 2014;262:36-55. doi:10.1111/imr.12223

10. Boven LA, van Meurs M, Boot RG, et al. Gaucher cells demonstrate a distinct macrophage phenotype and resemble alternatively activated macrophages. Am J Clin Pathol. 2004;122:359-369. doi:10.1309/BG5VA8JRDQH1M7HN

11. Gören Şahin D, Üsküdar Teke H, Karagülle M, et al. Gaucher cells or pseudo-Gaucher cells: that's the question. Turk J Haematol. 2014;31:428-429. doi:10.4274/tjh.2014.0019

12. Medrano-Engay B, Irun $P$, Gervas-Arruga J, et al. Iron homeostasis and inflammatory biomarker analysis in patients with type 1 Gaucher disease. Blood Cells Mol Dis. 2014;53:171-175. doi:10.1016/j.bcmd.2014.07.007

13. Regenboog $M$, van Kuilenburg AB, Verheij $J$, et al Hyperferritinemia and iron metabolism in Gaucher disease: potential pathophysiological implications. Blood Rev. 2016;30:431-437. doi:10.1016/j.blre.2016.05.003

14. Arends $M$, van Dussen L, Biegstraaten M, Hollak CE. Malignancies and monoclonal gammopathy in Gaucher disease; a systematic review of the literature. $\mathrm{Br} J$ Haematol. 2013;161:832-842. doi:10.1111/bjh.12335

15. Limgala RP, Ioanou C, Plassmeyer M, et al. Time of initiating enzyme replacement therapy affects immune abnormalities and disease severity in patients with Gaucher disease. PLoS One. 2016;11:e0168135. doi:10.1371/journal.pone.0168135
16. Mitrovic M, Elezovic I, Miljic P, Suvajdzic N. Acquired von Willebrand syndrome in patients with Gaucher disease. Blood Cells Mol Dis. 2014;52:205-207. doi:10.1016/j.bcmd.20 13.11 .001

17. Spectre G, Roth B, Ronen G, et al. Platelet adhesion defect in type I Gaucher disease is associated with a risk of mucosal bleeding. Br J Haematol. 2011;153:372-378. doi:10.1111/ j.1365-2141.2011.08613.x

18. Mehta A. Gaucher disease: unmet treatment needs. Acta Paediatr. 2008;97:83-87. doi:10.1111/j.1651-2227.2008.00653.x

19. Page MJ, McKenzie JE, Bossuyt PM, et al. The PRISMA 2020 statement: an updated guideline for reporting systematic reviews. PLoS Med. 2021;18:e1003583. doi:10.1371/journal.pmed.10 03583

20. Medoff AS, Bayrd ED. Gaucher's disease in 29 cases: hematologic complications and effect of splenectomy. Ann Intern Med. 1954;40:481-492.

21. Giraldo P, Pérez-López J, Núñez R, et al. Patients with type 1 Gaucher disease in Spain: a cross-sectional evaluation of health status. Blood Cells Mol Dis. 2016;56:23-30. doi:10.1016/j. bcmd.2015.10.001

22. Charrow J, Esplin JA, Gribble TJ, et al. Gaucher disease: recommendations on diagnosis, evaluation, and monitoring. Arch Intern Med. 1998;158:1754-1760. doi:10.1001/archinte.158.16.1754

23. Essabar L, Meskini T, Lamalmi N, et al. Gaucher's disease: report of 11 cases with review of literature. Pan Afr Med J. 2015;20:18. doi:10.11604/pamj.2015.20.18.4112

24. Niederau C, Häussinger D. Gaucher's disease: a review for the internist and hepatologist. Hepatogastroenterology. 2000;47:984-997.

25. Niederau C, Rolfs A, Vom Dahl S, et al. Diagnose und Therapie des Morbus Gaucher. Aktuelle Empfehlungen der deutschen Therapiezentren im Jahr 2000 [Diagnosis and therapy of Gaucher disease. Current recommendations of German therapy centers in the year 2000]. Med Klin (Munich). 2001;96:32-39. doi:10.1007/PL00002150

26. Belmatoug N, Caubel I, Stirnemann J, Billette de Villemeur T. La maladie de Gaucher [Gaucher's disease]. J Soc Biol. 2002;196:141-149. doi:10.1051/jbio/2002196020141

27. Giraldo P, Pocoví M, Pérez-Calvo J, et al. Report of the Spanish Gaucher's disease registry: clinical and genetic characteristics. Haematologica. 2000;85:792-799.

28. Weinreb NJ, Camelo JS Jr, Charrow J, et al.; International Collaborative Gaucher Group (ICGG) Gaucher Registry (NCT00358943) investigators. Gaucher disease type 1 patients from the ICGG Gaucher Registry sustain initial clinical improvements during twenty years of imiglucerase treatment. Mol Genet Metab. 132;2021:100-111. doi:10.1016/j.ymgme.2020.12.295

29. Zimran A, Altarescu G, Rudensky B, et al. Survey of hematological aspects of Gaucher disease. Hematology. 2005;10:151-156. doi:10.1080/10245330500067181

30. Mistry PK, Batista JL, Andersson HC, et al. Transformation in pretreatment manifestations of Gaucher disease type 1 during two decades of alglucerase/imiglucerase enzyme replacement therapy in the International Collaborative Gaucher Group (ICGG) Gaucher Registry. Am J Hematol. 2017;92:929-939. doi:10.1002/ajh.24801

31. Thomas AS, Mehta AB, Hughes DA. Diagnosing Gaucher disease: an on-going need for increased awareness amongst haematologists. Blood Cells Mol Dis. 2013;50:212-217. doi:10.1016/j.bcmd.2012.11.004

32. Hughes D. Gaucher disease: hematologic and oncologic implications. Clin Adv Hematol Oncol. 2011;9:771-772. 
33. Linari S, Castaman G. Hematological manifestations and complications of Gaucher disease. Expert Rev Hematol. 2016;9:51-58. doi:10.1586/17474086.2016.1112732

34. Zimran A, Belmatoug N, Bembi B, et al. Demographics and patient characteristics of 1209 patients with Gaucher disease: descriptive analysis from the Gaucher Outcome Survey (GOS). Am J Hematol. 2018;93:205-212. doi:10.1002/ajh.24957

35. Puri RD, Kapoor S, Kishnani PS, et al.; Gaucher Disease Task Force. Diagnosis and management of Gaucher disease in India consensus guidelines of the Gaucher Disease Task Force of the Society for Indian Academy of Medical Genetics and the Indian Academy of Pediatrics. Indian Pediatr. 2018;55:143-153. doi:10.1007/s13312-018-1249-9

36. Hughes DA, Pastores GM. Haematological manifestations and complications of Gaucher disease. Curr Opin Hematol. 2013;20:41-47. doi:10.1097/MOH.0b013e32835a9148

37. Andrade-Campos MM, de Frutos LL, Cebolla JJ, et al. Identification of risk features for complication in Gaucher's disease patients: a machine learning analysis of the Spanish registry of Gaucher disease. Orphanet J Rare Dis. 2020;15:256. doi:10.1186/s13023-020-01520-7

38. Revel-Vilk S, Szer J, Zimran A. Hematological manifestations and complications of Gaucher disease. Expert Rev Hematol. 2021;14:347-354. doi:10.1080/17474086.2021.1908120

39. Wasserstein MP, Caggana M, Bailey SM, et al. The New York pilot newborn screening program for lysosomal storage diseases: report of the first 65,000 infants. Genet Med. 2019;21:631-640. doi:10.1038/s41436-018-0129-y

40. Navarrete-Martínez JI, Limón-Rojas AE, Gaytán-García MJ, et al. Newborn screening for six lysosomal storage disorders in a cohort of Mexican patients: three-year findings from a screening program in a closed Mexican health system. Mol Genet Metab. 2017;121:16-21. doi:10.1016/j.ymgme.2017.03.001

41. Burlina AB, Polo G, Salviati L, et al. Newborn screening for lysosomal storage disorders by tandem mass spectrometry in North East Italy. J Inherit Metab Dis. 2018;41:209-219. doi:10.1007/s10545-017-0098-3

42. Burton BK, Charrow J, Hoganson GE, et al. Screening for lysosomal storage disorders in Illinois: the initial 15-month experience. $J$ Pediatr. 2017;190:130-135. doi:10.1016/j. jpeds.2017.06.048

43. Elliott S, Buroker N, Cournoyer JJ, et al. Pilot study of newborn screening for six lysosomal storage diseases using Tandem Mass Spectrometry. Mol Genet Metab. 2016;118:304-309. doi:10.1016/ j.ymgme.2016.05.015

44. Kang L, Zhan X, Gu X, Zhang H. Successful newborn screening for Gaucher disease using fluorometric assay in China. J Hum Genet. 2017;62:763-768. doi:10.1038/jhg.2017.36

45. Liao HC, Chiang CC, Niu DM, et al. Detecting multiple lysosomal storage diseases by tandem mass spectrometry-a national newborn screening program in Taiwan. Clin Chim Acta. 2014;431:80-86. doi:10.1016/j.cca.2014.01.030

46. Camargo Neto E, Schulte J, Pereira J, et al. Neonatal screening for four lysosomal storage diseases with a digital microfluidics platform: initial results in Brazil. Genet Mol Biol. 2018;41:414-416. doi:10.1590/1678-4685-gmb-2017-0227

47. Sanders KA, Gavrilov DK, Oglesbee D, et al. A comparative effectiveness study of Newborn screening methods for four lysosomal storage disorders. Int J Neonatal Screen. 2020;6:44. doi:10.3390/ijns6020044

48. Málaga DR, Brusius-Facchin AC, Siebert M, et al. Sensitivity, advantages, limitations, and clinical utility of targeted next-generation sequencing panels for the diagnosis of selected lysosomal storage disorders. Genet Mol Biol. 2019;42(1 suppl 1):197-206. doi:10.1590/1678-4685-gmb-2018-0092
49. Lei K, Zhao Y, Sun L, et al. A pilot screening of high-risk Gaucher disease children using dried blood spot methods in Shandong province of China. Orphanet J Rare Dis. 2018;13:48. doi:10.1186/s13023-018-0782-x

50. Huang Y, Jia X, Tang C, et al. High risk screening for Gaucher disease in patients with splenomegaly and/or thrombocytopenia in China: 55 cases identified. Clin Chim Acta. 2020;506:22-27. doi:10.1016/j.cca.2020.03.016

51. Motta I, Filocamo M, Poggiali E, et al.; Splenomegaly Gaucher Disease study group. A multicentre observational study for early diagnosis of Gaucher disease in patients with Splenomegaly and/ or Thrombocytopenia. Eur $J$ Haematol. 2016;96:352-359. doi:10.1111/ejh.12596

52. Miyamoto T, Iino M, Komorizono Y, et al. Screening for Gaucher disease using dried blood spot tests: a Japanese Multicenter, Cross-sectional Survey. Intern Med. 2021;60:699-707. doi:10.2169/internalmedicine.5064-20

53. Andrade-Campos M, Alfonso P, Irun P, et al. Diagnosis features of pediatric Gaucher disease patients in the era of enzymatic therapy, a national-base study from the Spanish Registry of Gaucher Disease. Orphanet $J$ Rare Dis. 2017;12:84. doi:10.1186/s13023-017-0627-z

54. Giraldo P, López de Frutos L, Cebolla JJ. Biomarker combination is necessary for the assessment of Gaucher disease? Ann Transl Med. 2018;6(Suppl 1):S81. doi:10.21037/atm.2018.10.69

55. Fuller M, Tucker JN, Lang DL, et al. Screening patients referred to a metabolic clinic for lysosomal storage disorders. J Med Genet. 2011;48:422-425. doi:10.1136/jmg.2010.088096

56. Tang C, Jia X, Tang F, et al. Detection of glucosylsphingosine in dried blood spots for diagnosis of Gaucher disease by LC-MS/ MS. Clin Biochem. 2021;87:79-84. doi:10.1016/j. clinbiochem.2020.10.011

57. Mistry PK, Cappellini MD, Lukina E, et al. A reappraisal of Gaucher disease-diagnosis and disease management algorithms. Am J Hematol. 2011;86:110-115. doi:10.1002/ajh.21888

58. Di Rocco M, Andria G, Deodato F, et al. Early diagnosis of Gaucher disease in pediatric patients: proposal for a diagnostic algorithm. Pediatr Blood Cancer. 2014;61:1905-1909. doi: $10.1002 /$ pbc. 25165

59. Mehta A, Kuter DJ, Salek SS, et al. Presenting signs and patient co-variables in Gaucher disease: outcome of the Gaucher Earlier Diagnosis Consensus (GED-C) Delphi initiative. Intern Med J. 2019;49:578-591. doi:10.1111/imj.14156

60. Billett HH, Rizvi S, Sawitsky A. Coagulation abnormalities in patients with Gaucher's disease: effect of therapy. Am J Hematol. 1996;51:234-236. doi:10.1002/(SICI)1096-8652(199603) $51: 3<234::$ AID-AJH9>3.0.CO;2-Y

61. Hollak CE, Levi M, Berends F, et al. Coagulation abnormalities in type 1 Gaucher disease are due to low-grade activation and can be partly restored by enzyme supplementation therapy. $\mathrm{Br}$ $J$ Haematol. 1997;96:470-476. doi:10.1046/j.1365-2141.1997. d01-2076.x

62. Katz K, Tamary H, Lahav J, et al. Increased operative bleeding during orthopaedic surgery in patients with type I Gaucher disease and bone involvement. Bull Hosp Jt Dis. 1999;58:188-190.

63. Giona F, Palumbo G, Amendola A, et al. Platelet function and coagulation abnormalities in type 1 Gaucher disease patients: effects of enzyme replacement therapy (ERT). J Thromb Haemost. 2006;4:1831-1833. doi:10.1111/j.1538-7836.2006.02037.x

64. Deghady A, Marzouk I, El-Shayeb A, Wali Y. Coagulation abnormalities in type 1 Gaucher disease in children. Pediatr Hematol Oncol. 2006;23:411-417. doi:10.1080/0888001060 0623232

65. Mitrovic M, Antic D, Elezovic I, et al. Haemostatic abnormalities in treatment-naïve patients with type 1 Gaucher's disease. Platelets. 2012;23:143-149. doi:10.3109/09537104.2011.597526 
66. Givol N, Goldstein G, Peleg O, et al. Thrombocytopenia and bleeding in dental procedures of patients with Gaucher disease. Haemophilia. 2012;18:117-121. doi:10.1111/j.13652516.2011.02540.x

67. Komninaka V, Repa K, Marinakis T, et al. Platelet function defects in patients with Gaucher disease on long term ERTimplications for evaluation at bleeding challenges. Blood Cells Mol Dis. 2020;80:102371. doi:10.1016/j.bcmd.2019.102371

68. Rosenbaum H. Hemorrhagic aspects of Gaucher disease. Rambam Maimonides Med J. 2014;5(4):e0039. doi:10.5041/RMMJ.10173

69. Mitrovic M, Elezovic I, Grujicic D, et al. Complex haemostatic abnormalities as a cause of bleeding after neurosurgery in a patient with Gaucher disease. Platelets. 2015;26:260-262. doi:10.3109/09537104.2014.903471

70. Clarkson CP, Magann EF, Siddique SA, Morrison JC. Hematological complications of Gaucher's disease in pregnancy. Mil Med. 1998;163:499-501. doi:10.1093/milmed/163.7.499

71. Granovsky-Grisaru S, Belmatoug N, Vom Dahl S, et al. The management of pregnancy in Gaucher disease. Eur J Obstet Gynecol Reprod Biol. 2011;156:3-8. doi:10.1016/j. ejogrb.2010.12.024

72. Rosenbaum H. Management of women with Gaucher disease in the reproductive age. Thromb Res. 2015;135(Suppl 1):S49-51. doi:10.1016/S0049-3848(15)50443-X

73. Hollak CE, Maas M, Aerts JM. Clinically relevant therapeutic endpoints in type I Gaucher disease. J Inherit Metab Dis. 2001;24 (Suppl 2):97-105;87-8. doi:10.1023/A:1012492429191

74. Pastores GM, Weinreb NJ, Aerts H, et al. Therapeutic goals in the treatment of Gaucher disease. Semin Hematol. 2004;41(4 Suppl 5):4-14. doi:10.1053/j.seminhematol.2004.07.009

75. Weinreb NJ, Finegold DN, Feingold E, et al. Evaluation of disease burden and response to treatment in adults with type 1 Gaucher disease using a validated disease severity scoring system (DS3). Orphanet J Rare Dis. 2015;10:64. doi:10.1186/s13023015-0280-3

76. Biegstraaten M, Cox TM, Belmatoug N, et al. Management goals for type 1 Gaucher disease: an expert consensus document from the European working group on Gaucher disease. Blood Cells Mol Dis. 2018;68:203-208. doi:10.1016/j.bcmd.2016.10.008

77. Shemesh E, Deroma L, Bembi B, et al. Enzyme replacement and substrate reduction therapy for Gaucher disease. Cochrane Database Syst Rev. 2015;3:CD010324.

78. Mankin HJ, Trahan CA, Barnett NA, et al. A questionnaire study for 128 patients with Gaucher disease. Clin Genet. 2006;69:209-217. doi:10.1111/j.1399-0004.2006.00573.x

79. Piran S, Roberts A, Patterson MA, Amato D. The clinical course of untreated Gaucher disease in 22 patients over 10 years: hematological and skeletal manifestations. Blood Cells Mol Dis. 2009;43:289-293. doi:10.1016/j.bcmd.2009.08.002

80. Gielchinsky Y, Elstein D, Green R, et al. High prevalence of low serum vitamin $\mathrm{B} 12$ in a multi-ethnic Israeli population. $\mathrm{Br}$ J Haematol. 2001;115:707-709. doi:10.1046/j.13652141.2001.03156.x

81. Wine E, Yaniv I, Cohen IJ. Hyperimmunoglobulinemia in pediatric-onset type 1 Gaucher disease and effects of enzyme replacement therapy. $J$ Pediatr Hematol Oncol. 2007;29:451-457. doi:10.1097/MPH.0b013e31806451d3

82. Sender SU, Limgala RP, Ivanova MM, et al. Persistent immune alterations and comorbidities in splenectomized patients with Gaucher disease. Blood Cells Mol Dis. 2016;59:8-15. doi:10.1016/j.bcmd.2016.02.003

83. Gervas-Arruga J, Cebolla JJ, de Blas I, et al. The influence of genetic variability and proinflammatory status on the development of bone disease in patients with Gaucher disease. PLoS One. 2015;10(5):e0126153. doi:10.1371/journal.pone.0126153
84. Pandey MK, Burrow TA, Rani R, et al. Complement drives glucosylceramide accumulation and tissue inflammation in Gaucher disease. Nature. 2017;543:108-112. doi:10.1038/ nature 21368

85. Shiran A, Brenner B, Laor A, Tatarsky I. Increased risk of cancer in patients with Gaucher disease. Cancer. 1993;72:219-224. doi:10.1002/1097-0142(19930701)72:1<219::AIDCNCR2820720139>3.0.CO;2-Y

86. Reardon M, Cotter P, Kealy WF, Duggan PF. Gaucher's disease with haematological complications. Ir Med J. 1993;86:39-40.

87. de Lonlay P, Fenneteau O, Touati G, et al. Manifestations hématologiques dans les erreurs innées du métabolisme [Hematologic manifestations of inborn errors of metabolism]. Arch Pediatr. 2002;9:822-835. doi:10.1016/S0929-693X(02) 00005-2

88. Elias AF, Johnson MR, Boitnott JK, Valle D. Neonatal cholestasis as initial manifestation of type 2 Gaucher disease: a continuum in the spectrum of early onset Gaucher disease. JIMD Rep. 2012;5:95-98.

89. Vom Dahl S, Mengel E. Lysosomal storage diseases as differential diagnosis of hepatosplenomegaly. Best Pract Res Clin Gastroenterol. 2010;24:619-628. doi:10.1016/j.bpg.2010.09.001

90. Rosenbloom BE, Weinreb NJ, Zimran A, et al. Gaucher disease and cancer incidence: a study from the Gaucher Registry. Blood. 2005;105:4569-4572. doi:10.1182/blood-2004-12-4672

91. Zimran A, Liphshitz I, Barchana M, et al. Incidence of malignancies among patients with type I Gaucher disease from a single referral clinic. Blood Cells Mol Dis. 2005;34:197-200. doi:10.1016/j.bcmd.2005.03.004

92. Costello R, O’Callaghan T, Baccini V, Sébahoun G. Aspects hématologiques de la maladie de Gaucher [Hematological aspects of Gaucher disease]. Rev Med Interne. 2007;28(Suppl 2):S176-9. doi:10.1016/S0248-8663(07)78877-X

93. de Fost M, Vom Dahl S, Weverling GJ, et al. Increased incidence of cancer in adult Gaucher disease in Western Europe. Blood Cells Mol Dis. 2006;36:53-58. doi:10.1016/j.bcmd.2005.08.004

94. Taddei TH, Kacena KA, Yang M, et al. The underrecognized progressive nature of N370S Gaucher disease and assessment of cancer risk. Am J Hematol. 2009;84:208-214. doi:10.1002/ ajh. 21362

95. Lo SM, Stein P, Mullaly S, et al. Expanding spectrum of the association between Type 1 Gaucher disease and cancers: a series of patients with up to 3 sequential cancers of multiple typescorrelation with genotype and phenotype. Am J Hematol. 2010;85:340-345. doi:10.1002/ajh.21684

96. Weinreb NJ, Lee RE. Causes of death due to hematological and non-hematological cancers in 57 US patients with type 1 Gaucher Disease who were never treated with enzyme replacement therapy. Crit Rev Oncog. 2013;18:177-195. doi:10.1615/ CritRevOncog.2013005921

97. Weinreb NJ, Barbouth DS, Lee RE. Causes of death in 184 patients with type 1 Gaucher disease from the United States who were never treated with enzyme replacement therapy. Blood Cells Mol Dis. 2018;68:211-217. doi:10.1016/j. bcmd.2016.10.002

98. Mistry PK, Taddei T, Vom Dahl S, Rosenbloom BE. Gaucher disease and malignancy: a model for cancer pathogenesis in an inborn error of metabolism. Crit Rev Oncog. 2013;18:235-246. doi:10.1615/CritRevOncog.2013006145

99. Rodic P, Pavlovic S, Kostic T, et al. Gammopathy and B lymphocyte clonality in patients with Gaucher type I disease. Blood Cells Mol Dis. 2013;50:222-225. doi:10.1016/j. bcmd.2012.11.012

100. Cox TM, Rosenbloom BE, Barker RA. Gaucher disease and comorbidities: b-cell malignancy and parkinsonism. Am J Hematol. 2015;90(Suppl 1):S25-8. doi:10.1002/ajh.24057 
101. Nair S, Branagan AR, Liu J, et al. Clonal immunoglobulin against lysolipids in the origin of myeloma. $N$ Engl $J$ Med. 2016;374:555-561. doi:10.1056/NEJMoa1508808

102. Nair S, Bar N, Xu ML, et al. Glucosylsphingosine but not Saposin C, is the target antigen in Gaucher disease-associated gammopathy. Mol Genet Metab. 2020;129:286-291. doi:10.1016/j.ymgme.2020.01.009

103. Ranade A, Chintapatla R, Varma M, Sandhu G. Hematologic manifestations and leukemia in Gaucher's disease. Clin Adv Hematol Oncol. 2013;11:253-255.

104. Shvidel L, Hurwitz N, Shtalrid M, et al. Complex IgA gammopathy in Gaucher's disease. Leuk Lymphoma. 1995;20:165-168. doi:10.3109/10428199509054770

105. Martinez-Redondo C, Ortuño FJ, Lozano ML, et al. IgM monoclonal component associated with type I Gaucher disease resolved after enzyme replacement therapy: a case report. $J$ Inherit Metab Dis. 2009;32(Suppl 1):S265-7. doi:10.1007/s10545-009-1207-8

106. Perales M, Cervantes F, Cobo F, Montserrat E. Non-Hodgkin's lymphoma associated with Gaucher's disease. Leuk Lymphoma. 1998;31:609-612. doi:10.3109/10428199809057621

107. Shvidel L, Sigler E, Shtalrid M, et al. Parotid gland involvement, the presenting sign of high grade non-Hodgkin lymphoma in two patients with Gaucher disease and sicca syndrome. J Inherit Metab Dis. 2007;30:825. doi:10.1007/s10545-007-0610-2

108. Zimran A, Ruchlemer R, Revel-Vilk S. A patient with Gaucher disease and plasma cell dyscrasia: bidirectional impact. Hematology Am Soc Hematol Educ Program. 2020;2020:389-394. doi:10.1182/hematology.2020000123

109. Monge J, Chadburn A, Gergis U. Synchronous multiple myeloma and Gaucher disease. Hematol Oncol Stem Cell Ther. 2020;13:42-45. doi:10.1016/j.hemonc.2019.07.001

110. Hawkesford MP, Bowey AJ, Rao J, Meara NJ. Synchronous presentation of Gaucher disease and solitary plasmacytoma with progression to multiple myeloma. Scott Med J. 2011;56:236. doi:10.1258/smj.2011.011178

111. Kim MJ, Suh JT, Lee HJ, et al. Simultaneous detection of Gaucher's disease and renal involvement of non-Hodgkin's lymphoma: the first Asian case report and a review of literature. Ann Clin Lab Sci. 2012;42:293-301.

112. Haliloglu M, Hoffer FA, Haight AE, Cunningham JM. BuddChiari syndrome caused by Gaucher's disease. Pediatr Radiol. 1999;29:908-910. doi:10.1007/s002470050723

113. Miri-Moghaddam E, Velayati A, Naderi M, et al. Coinheritance of Gaucher disease and $\alpha$-thalassemia resulting in confusion between two inherited hematologic diseases. Blood Cells Mol Dis. 2011;46:88-91. doi:10.1016/j.bcmd.2010.08.007

114. Kose MD, Canda E, Kağnıcı M, et al. Coexistence of Gaucher disease and severe congenital neutropenia. Blood Cells Mol Dis. 2019;76:1-6. doi:10.1016/j.bcmd.2018.07.001

115. Lester TJ, Grabowski GA, Goldblatt J, et al. Immune thrombocytopenia and Gaucher's disease. Am J Med. 1984;77:569-571. doi:10.1016/0002-9343(84)90124-4

116. Maity P, Roy S, Das R, et al. Acute myeloid leukemia along with Gaucher disease in a child. Indian J Case Rep. 2021;5:211-213. doi:10.32677/IJCR.2021.v07.i05.012
117. Petrides PE, leCoutre P, Müller-Höcker J, et al. Coincidence of Gaucher's disease due to a private mutation and $\mathrm{Ph}$ ' positive chronic myeloid leukemia. Am J Hematol. 1998;59:87-90. doi:10.1002/(SICI)1096-8652(199809)59:1<87::AID-AJH17>3. $0 . \mathrm{CO} ; 2-\mathrm{Z}$

118. Villarrubia J, Rodríguez-Gambarte JD, Abalo L, et al. Gaucher disease and myelodysplastic syndrome with isolated del $(5 q) . \mathrm{Br}$ J Haematol. 2014;165:164. doi:10.1111/bjh.12798

119. Kubo T, Shimose S, Fujimori J, et al. Extraosseous extension caused by epidural hematoma in Gaucher disease mimicking malignant bone tumor. JIMD Rep. 2014;14:67-70.

120. Noya M, Andrade-Campos M, Irun P, et al. Gaucher disease and chronic myeloid leukemia: first reported patient receiving enzyme replacement and tyrosine kinase inhibitor therapies simultaneously. Clin Case Rep. 2018;6:887-892. doi:10.1002/ccr3.1460

121. Ruchlemer R, Mittelman M, Zimran A. Gaucher disease, myelodysplastic syndrome and ICUS. Blood Cells Mol Dis. 2020;80:102373. doi:10.1016/j.bcmd.2019.102373

122. Webb BD, Weinreb NJ, Botti AC, et al. JAK2V617F mutation and myeloproliferative malignancy in a patient with Type 1 Gaucher disease. Blood Cells Mol Dis. 2011;46:103-104. doi:10.1016/j.bcmd.2010.09.007

123. Lo SM, Choi M, Liu J, et al. Phenotype diversity in type 1 Gaucher disease: discovering the genetic basis of Gaucher disease/hematologic malignancy phenotype by individual genome analysis. Blood. 2012;119:4731-4740. doi:10.1182/blood-201110-386862

124. Hughes D, Cappellini MD, Berger M, et al. Recommendations for the management of the haematological and onco-haematological aspects of Gaucher disease. Br J Haematol. 2007;138:676-686. doi:10.1111/j.1365-2141.2007.06701.x

125. Mehta A, Belmatoug N, Bembi B, et al. Exploring the patient journey to diagnosis of Gaucher disease from the perspective of 212 patients with Gaucher disease and 16 Gaucher expert physicians. Mol Genet Metab. 2017;122:122-129. doi:10.1016/j. ymgme.2017.08.002

126. Deriaz S, Serratrice C, Lidove O, et al. Parcours diagnostique des patients atteints de maladie de Gaucher de type 1: enquête auprès de médecins internistes et hématologues [Diagnostic journey of type 1 Gaucher Disease patients: a survey including internists and hematologists]. Rev Med Interne. 2019;40:778-784. doi:10.1016/ j.revmed.2019.07.011

127. Mistry PK, Sadan S, Yang R, et al. Consequences of diagnostic delays in type 1 Gaucher disease: the need for greater awareness among hematologists-oncologists and an opportunity for early diagnosis and intervention. Am J Hematol. 2007;82:697-701. doi:10.1002/ajh.20908

128. Barth BM, Shanmugavelandy SS, Tacelosky DM, et al. Gaucher's disease and cancer: a sphingolipid perspective. Crit Rev Oncog. 2013;18:221-234. doi:10.1615/CritRevOncog.2013005814

129. Murugesan V, Chuang W-L, Liu J, et al. Glucosylsphingosine is a key biomarker of Gaucher disease. Am J Hematol. 2016;91 (11):1082-1089. doi:10.1002/ajh.24491
Journal of Blood Medicine

\section{Publish your work in this journal}

The Journal of Blood Medicine is an international, peer-reviewed, open access, online journal publishing laboratory, experimental and clinical aspects of all aspect pertaining to blood based medicine including but not limited to: Transfusion Medicine; Blood collection, Donor issues, Transmittable diseases, and Blood banking logistics; Immunohematology; Artificial and alternative blood based therapeutics; Hematology; Biotechnology/nanotechnology of blood related medicine; Legal aspects of blood medicine; Historical perspectives. The manuscript management system is completely online and includes a very quick and fair peer-review system Visit http://www.dovepress.com/testimonials.php to read real quotes from published authors. 